\title{
A Foundational Perspective for Spatial Thinking in Relation to Social Studies Curriculum and Middle- School Textbooks in Turkey
}

\author{
Sezgin ELBAY1 \\ Anadolu University, Eskişehir, TURKEY
}

IPh.D. candidate. Ministry of National Education, Social Studies Teacher, Sakarya, Turkey. sezgin_elbay [at] hotmail.com ORCID: 000-0002-0601-8063

\section{Abstract}

Social Studies is a middle-school course that unites social-science disciplines and contributes to developing an understanding about the social existence of humans. It is reported that existing studies have simply focused only on the 2005 Social Studies Curriculum and omitted focus on relevant textbooks. Within such a context the aim of the current study is to present the current state of spatial thinking skills in relation to the 2018 Social Studies Curriculum and middle-school textbooks in Turkey. Furthermore, the study aims to analyze the coordination that exists between curriculum and textbooks around spatial thinking. To achieve the aims of the current study, the technique of document analysis technique occurs through examination of Social Studies Curriculum and middleschool textbooks. By the end of this research it was detected that in the $5^{\text {th }}$ grade, the total number of opportunities for students to gain or develop the skills of spatial thinking was 8 , and the total number of units in the textbook about spatial thinking was 12; in the $6^{\text {th }}$ grade, the total number of opportunities for students to gain or develop the skills of spatial thinking was 7 , and the total number of units in textbook about spatial thinking was 12; and finally, in the $7^{\text {th }}$ grade, the total number of opportunities for students to gain or develop the skills of spatial thinking was 3 , and the total number of units in textbook about spatial thinking was 5 . Based on these results it can be argued that in Turkey there is not a full coordination or alignment between the 2018 Social Studies curriculum and relevant textbooks about spatial thinking.

\section{Keywords}

Social Studies Curriculum, Social Studies Textbooks, Spatial Thinking, Document Analysis, Foundational Research 
Social Studies education seeks to achieve effective adaptation of an individual into his/her social and physical environment. Within that context one of the generic objectives of Social Studies Curriculum is "To help students develop their ability to explain the interaction between humans and environment by learning about the general geographical features of the world and improve their spatial perception skills" (Ministry of National Education [MoNE], 2018, p. 8). In line with this objective, students are required to describe and analyze spatial features using an expanding-circle perspective from one's local environment to more distant environments. In doing so, students will be harnessing their skills of spatial perception. To that end a number of opportunities for students to acquire spatial thinking skills are embedded into Social Studies Curriculum.

In Social Studies Curriculum a majority of opportunities for students to gain or develop spatial thinking skills are in the learning area of People. Places and Environments. In the People, Places and Environments learning area "The aim is to help students know humans' interaction with the environment; by harnessing a number of relevant skills and assets, understanding causes and effects of this interaction and gaining a future-oriented personal or social stance" (MoNE, 2018, p. 11). Within such a context it is essential for students to explain the interrelationships between human activities and their spatial features, and to clarify these relationships by asking space-specific questions.

The National Council for the Social Studies (NCSS) reported that for students to develop spatial thinking they should ask space-specific questions. By asking questions such as 'where are they settled? Why are they settled into this particular environment? What is the definition of geographical environment? How do landforms change? And how do such changes affect human life?' an understanding about students' spatial-knowledge, spatial skills and spatial perspectives can be gained (NCSS, 2014). Furthermore, the answers for each question could be effective in activating an understanding about spatial-mental processes in students.

Spatial intelligence, as a component of Multiple Intelligence Theory (Carroll, 1993), can be defined as the ability to mentally rotate objects in the perceiving and construing one's environment. In alignment with that argument, spatial intelligence can also be defined as one's capacity to form imagery in line with a plan; and to also be able to mentally store, remember and transform the image at a later date (Lohman, 1996). In that sense it can be argued that spatial intelligence entails spatial relations and visualization (McGee, 1979; Pellegrino, Alderton \& Shute, 1984). Therefore, it can be stated that spatial thinking can improve the capacity of visualization, however, at this stage it is essential to form a conceptual agreement about spatial thinking.

The work of the National Research Council (NRC, 2006) enabled consensus to be reached about a definition for spatial thinking and spatial literacy. Before the work of the NRC was available, a range of definitions about spatial thinking were posted, such as spatial ability, spatial reasoning, spatial cognition, spatial intelligence and cognitive mapping (Gardner, 1983; Golledge \& Stimson, 1997; Kitchin \& Freundschuh, 2000; Newcombe \& Huttenlocher, 2000). It was then agreed that spatial thinking should be used as a comprehensive concept (NRC, 2006, p. 27). 
Spatial thinking can encompass all domains of life. In this context, spatial thinking can be used when any goal is too close or when a person is said to be involved in an event (Newcombe, 2010, p. 31). However, a literature analysis (Schultz, Kerski \& Patterson, 2008, p. 27) shows that spatial thinking calls for a number of skills to help people understand objects in their environment. Such skills allow individuals to describe, analyze and evaluate spatial relations (for instance place, distance, direction, form and region) between objects. Therefore, spatial relations can be included as a spatial thinking concept. For example, in an area where a disease is spread, earthquake, commerce, immigration etc. are the subjects that entail space-specific concepts (Öcal, 2007). Because while planning the diversity of activities in these areas (such as being an intersection point, a very busy or deserted center, being at the edge of the main roads, having factors that prevent settlement), spatial distribution and spatial order are taken into consideration. In the same vein, it can be claimed that spatial thinking skills can be developed and focused on through the use of educational tools such as maps, graphics, diagrams and models (Bednarz, 2007, quot. Madsen \& Rump, 2012, p. 100).

\section{Conceptual Framework}

\section{Spatial Thinking Skills}

Spatial thinking skills can be studied under three categories: spatial description, spatial analysis, and spatial evaluation.

Spatial description is defined as a reflexive mental activity that is a reflection of space on mind which provides an integrated system of space constructed with the part and the whole (Shemyakin, 1962, p. 190). Spatial description can occur through examining how living species meet their biological needs in natural environments. For example, by examining the space and actionbehaviors of ants and bees for their daily existence it can be feasible to gain further insights about the spatial patterns of behavior exhibited by these creatures (Öcal, 2007). On the other hand, other scholars define spatial description as a cognitive map. According to the cognitive map hypothesis, a brain saves a representation of the spatial environment in order to strengthen memory and guide future actions (Epstein, Patai, Julian \& Spiers, 2017). Based on the common points in these definitions it can be stated that spatial description considers any data related to the position of an environment. As an example, phenomenon like a street, mountain, village or sea that exists in a natural habitat can be saved in one's mind, thus, the individual can be drawn into questions about the locations. In such a context, spatially focused questions can be asked such as "how are new routes learned, how are routes between two locations remembered?" (Kitchin \& Freundschuh, 2018, p. 2).

Spatial analysis is based on building a connection between natural and human environmental features when learning about an environment. Hence, in spatial analysis, a connection is built between economic, physical and other relevant features of the population in an environment and activities of residents (Öcal, 2014). Therefore, locational features of an environment that can be analyzed and explored through certain visual features. 
Elbay, S. (2020). A Foundational Perspective for Spatial Thinking in Relation to Social Studies...

Spatial evolution is used to examine data about environmental features and transform such data into knowledge so that maximum benefit can be gained by people who wish to learn more about the chosen environment. For example, in a given geographical setting measures that people can take against natural disasters can be examined or potential environmental disasters can be detected. Also, a connection can be made between the lifestyle of residents (economic and social) and their closeness with nature, and this accumulated information can be used to protect environments and communities against natural disasters (Öcal, 2014). Consequently, it can be argued that in places most likely to experience natural disasters such as earthquakes, landslides or snow slides, a ban on any human settlements occurring there could be proof of conducting preliminary spatial analysis.

\section{Spatial Thinking in Educational Research}

It has been reported that the development of spatial thinking skills boosts mental performance (Behrmann, Geng \& Shomstein, 2004; Cohen et al., 1996). However, although spatial thinking skills are embedded into curriculums (Turkey 2018 Middle-School Social Studies and Secondary Education Geography) it is suggested that teachers believe that spatial thinking skills are merely about transferring spatial-data (Mutluer, 2013; Uğurlu \& Aladağ, 2015). Also, it is believed that certain problems are encountered in relation to bolstering the skills of spatial perception (Safi, 2010). These problems were reported as technical deficiencies in schools and inability to fully implement the constructivist curriculum. Within such scope it is suggested that teachers select curriculum and textbooks in relation to spatial thinking skills and then perform actual teaching as required.

Earlier studies on spatial thinking focused on a number of subjects. Some studies revealed that among pre-school children a difference existed between gender and the development of spatial thinking skills (Levine, Huttenlocher, Taylor \& Langrock, 1999). However, recent studies argue this difference can be mitigated through the use of video games (Feng, Spence \& Pratt, 2007) because it can be claimed that video games develop spatial thinking skills (Spence \& Feng, 2010). Studies which analyzed the place of spatial thinking skills in the 2005 Middle-School Social Studies Curriculum revealed that student acquisition of spatial thinking skills were greater in the $5^{\text {th }}$ and $6^{\text {th }}$ grades compared to the $7^{\text {th }}$ grade (Öcal, 2014; Uğurlu and Aladağ, 2015). The way in which the literature defines spatial thinking and the way teachers explain spatial thinking are not fully coordinated (Safi, 2010; Uğurlu and Aladağ, 2015). Some studies report that teachers of the social studies have very limited knowledge about spatial thinking (Mutluer, 2013 etc.) and a number of such studies were focused on the link between spatial thinking skills and the teaching of Geography (Ünlü and Yıldırım, 2017). A few studies aimed to measure students' spatial thinking skills (cognition) and it emerged that students in Middle-School $6^{\text {th }}$ grade faced difficulty in describing their school and home environment but had greater knowledge on more distant areas (Öcal, 2007). Other scholars compared space cognition and map-reading skills of college students in departments of social studies and preschool teaching, and found a significant difference in favor of students from social studies (Merç, 2011 ). 
Very few studies focused on spatial thinking skills in the Middle-School Social Studies Curriculum, and these studies were reportedly about Social Studies Curriculum developed in 2005 (for instance Öcal, 2014; Uğurlu and Aladağ, 2015). However, in the 2018 Social Studies Curriculum there may be a difference in terms of grade level and opportunities for the acquisitions of spatial thinking skills compared to the 2005 Social Studies Curriculum. The Ministry of National Education, Board of Education (who design the Middle-School Social Studies Textbooks) say there is a void in the way spatial skill domains are distributed, so it is unknown if there is a coordination between Social Studies Curriculum and related textbooks in terms of spatial skill domains even though coordination between curriculum and textbooks are required (Pehlivan and Kolaç 2016; Taş, 2007).

By examining the 2018 Middle-School Social Studies Curriculum and related textbooks, a document analysis approach provides a viable way to measure the way in which spatial skill domains are distributed and whether or not they are coordinated between curriculum and textbook. Hence curriculum-development specialists and authors of the textbooks (course-book) can broaden their horizon on this issue and teachers can alleviate their misconceptions. New models of coordination between curriculum and textbooks can be developed and eventually studies about the development of students' spatial thinking skills can be boosted. Within such a context, the aim of this study is to describe the coordination between the 2018 Middle-School Social Studies Curriculum and the relevant middle-school textbooks about spatial thinking skills. The research questions used to frame the current study are below:

- For $5^{\text {th }}$ grade: What is the distribution of opportunities for students to acquire spatial thinking skills across learning areas in the 2018 Middle School Social Studies Curriculum and units in the relevant textbook?

- For $6^{\text {th }}$ grade: What is the distribution of opportunities for students to acquire spatial thinking skills across learning areas in the 2018 Middle School Social Studies Curriculum and units in the relevant textbook?

- For $7^{\text {th }}$ grade: What is the distribution of opportunities for students to acquire spatial thinking skills across learning areas in the 2018 Middle School Social Studies Curriculum and units in the relevant textbook?

\section{Methodology}

Qualitative research method has been employed to answer the research questions. Qualitative research is a method based on interpreting findings that emerge from the opinions of individuals, groups or relevant documents (Creswell, 2013). Within that context, as also argued by Lincoln and Guba (1985), this paper reflects a paradigmatic hypothesis of a naturalist revision. To that end a qualitative research has been modeled to examine the coordination between the 2018 Middle-School Social Studies Curriculum and Board of Education (BoE)designed textbooks in relation to opportunities for students to acquire and develop spatial thinking skills.

\section{Research Design}

Research is built upon examining the 2018 Middle-School Social Studies Curriculum and BoE-designed textbooks through using document analysis 
Elbay, S. (2020). A Foundational Perspective for Spatial Thinking in Relation to Social Studies...

model. Document analysis is based on examining print and visual materials that contain certain data related to any case or phenomenon to be investigated (Yıldıım and Şimşek, 2013). Documents can either be journals, photographs, dairies, letters, official documents, autobiography or biography records (Creswell, 2013). The main conditions for document analysis are based on a research topic and a combinined examination of the relevant document to reach a common ground about understanding the trends or views emerging from the content of the documents (Karasar, 2007). Document analysis can be a data collection method in itself, and it can also be used collectively with other data-collection methods (Yıldırım and Şimşek, 2013). Within such a context the 2018 Social Studies Curriculum and the relevant social studies textbooks issued by BoE for grades 5, 6 and 7 have been examined in terms of the opportunities provided for students to acquire and develop spatial thinking skills. Analysis focused on the opportunities for students to acquire and develop spatial thinking skills from the learning areas in the curriculum and the contexts of units in the textbooks.

Sampling Method. In this research standard sampling, has been harnessed as one of the qualitative research-sampling methods, and research data were purposefully collected. Criterion has been set as MoNE's (Ministry of National Education) 2018 Middle-School Social Studies Curriculum and the official BoE textbooks for grades 5,6 , and 7 . Therefore, it was viable to perform consistency checks in official publications, and relevant shareholders, such as curriculumdevelopment specialists, social-studies trainers and teachers, could be informed about feasible suggestions.

\section{Data Collection and Analysis}

For document analysis the 2018 Middle School Social Studies Curriculum and the BoE social studies textbooks for grade 5, 6 and 7 were analyzed. Documents were accessed from the MoNE official-website (http://mufredat.meb.gov.tr/ProgramDetay.aspx?PID=354;http://www.eba.gov .tr/ekitap? channel=8). Within such a context, and based on a predetermined analysis of units selected by researcher, the chosen documents were evaluated based on opportunities for students to acquire and develop spatial thinking skills. Certain trends were identifiable in these documents. The areas for analysis focused on opportunities for students to acquire or develop spatial thinking skills across learning areas of the curriculum and in the corresponding units of the textbooks. Texts, visuals and questions in the textbooks formed the minimum analysis of the units. The areas of analysis are shown in table 1 and spatial thinking skills are rated according to the definitions of these skills. 
Table 1

Tool for Determining Spatial Thinking Skills Included in Unit Contents in Social Studies Textbooks

\begin{tabular}{lllll}
\hline $\begin{array}{l}\text { Unit contents of } \\
\text { social studies } \\
\text { textbook }\end{array}$ & \multicolumn{3}{l}{ The position of spatial thinking skills in textbooks } \\
\cline { 2 - 4 } & Spatial description & Spatial analysis & Spatial evaluation \\
\cline { 2 - 4 } & Number Image & Number of Image & Number Image \\
of pages number & pages & number & of pages number \\
\hline $\begin{array}{l}\text { Pre-text preparation } \\
\text { and sub-text } \\
\text { questions }\end{array}$ & & & \\
\hline Let's think and & & & \\
discuss & & & \\
\hline It is your turn & & & \\
\hline Reading text & & & \\
\hline Let's investigate & & \\
and share & & & \\
\hline Images (all kinds of \\
visual evidence, \\
such as maps, \\
figures)
\end{tabular}

Context analysis was conducted on data collected from the documents. Context analysis involves deciphering the language of documents, exposing the means in texts or discourses, and systematizing the findings (Coolican, 2009). Hence in this study, context analysis was used to determine the occurrence of opportunities for students to acquire and develop spatial thinking skills in the 2018 Middle-School Social Studies Curriculum and the BoE social studies textbooks for grades 5,6 and 7 .

Firstly, spatial thinking skills in the 2018 Middle School Social Studies Curriculum were determined in the study. In that sense the opportunities for students to acquire and develop spatial thinking skills were analyzed. In order to measure to what extent spatial thinking skills are represented, the researcher designed a "Skill Analysis List" and presented it to the field specialists (see Annex 1 for an example of the analysis list). The intent of the skills-checklist was to detect spatial thinking skills in the curriculum. Also, in order to see to which spatial thinking skills are appropriate for texts, visuals and questions in textbooks, another skill-analysis list was developed and submitted to field specialists. Within that context, the spatial description, analysis and evaluation skills were given codes and opportunities for students to acquire and develop spatial thinking skills in the curriculum and texts, visuals and questions of the textbooks were analyzed. Analysis results were digitized and displayed in tables and figures.

\section{Validity and Reliability of Research}

Data obtained from skill analysis list were assessed in terms of consensus and conflict and a common ground was reached. Hence, a reliability formula Reliability=Consensus/(Consensus+Dissensus), was employed (Miles \& Huberman, 1994). A score of $70 \%$ and higher is deemed to be sufficient for reliability (Miles and Huberman, 1994). After computation coding reliability was completed, the scores were $75 \%$ for acquisition opportunity in the curriculum; $80 \%$ for the BoE textbook for grade 5; $80 \%$ for the BoE textbook for grade 6; and $85 \%$ for the BoE textbook for grade 7 . Such values indicate the reliability of research findings. 
Elbay, S. (2020). A Foundational Perspective for Spatial Thinking in Relation to Social Studies...

In qualitative research, a review of data analysis by a colleague or an independent field specialist may elevate reliability (Coolican, 2009; Glesne and Peshkin, 1992; Roberts and Priest, 2006). The current research data analysis and findings were submitted to a colleague for external auditing and feedback was received about the data analysis process. Such a practice is also known as analyst triangulation. Analyst triangulation involves conducting an independent analysis on data by one or more people, and drawing a comparison across analyses (Patton, 2014).

To check internal consistency, a revision was conducted to see if the analyzed research concepts matched with the context and if consistency prevailed between provided context and obtained findings (Maxwell, 1992). To that end, findings were garnered by revealing the relationship of obtained data from documents with the context. To provide external validity, the sampling was matched with the topic to be examined (Maxwell, 1992). In that sense, documents were selected to match the topic and the aim of research and steps to follow in research pattern, sampling method, data collection and analysis processes were explained.

\section{Limitation}

This research is limited with Social Studies Curriculum developed in 2018 for Middle-Schools by MONE and 5, 6 and 7th grade social studies textbooks designed by BoE in line with the curriculum; the said curriculum and learning area, acquisition and unit contexts related to spatial thinking skills in textbooks with Social Studies Curriculum developed in 2018 for Middle-Schools by MoNE and 5,6 and 7 th grade social studies textbooks designed by BoE in line with the program; the said curriculum and learning area, acquisition and unit contexts related to spatial thinking skills in textbooks.

\section{Results}

\section{Grade 5: What Is the Distribution of Spatial Thinking Skills with Respect to Learning Area, Unit and Acquisitions?}

In grade 5 of the Social Studies Curriculum, the distribution of spatial thinking skills for learning area, unit and acquisitions are displayed in Table 2.

Table 2.

For the Grade 5 Level of Social Studies Curriculum; Distribution of Spatial Thinking Skills for Learning Area, Unit and Acquisitions

\begin{tabular}{|c|c|c|c|}
\hline Learning area & Unit & Acquisition & Spatial skill \\
\hline $\begin{array}{l}\text { Culture and } \\
\text { Heritage }\end{array}$ & Beauties around & $\begin{array}{l}\text { The student can describe natural } \\
\text { assets around as well as historical } \\
\text { places, objects and artifacts. }\end{array}$ & $\begin{array}{l}\text { Spatial } \\
\text { description }\end{array}$ \\
\hline & Landforms & $\begin{array}{l}\text { On maps s/he can explain } \\
\text { landforms of the place s/he lives in } \\
\text { and its surrounding in general. }\end{array}$ & $\begin{array}{l}\text { Spatial } \\
\text { description }\end{array}$ \\
\hline & $\begin{array}{l}\text { Climate effect on } \\
\text { human activities }\end{array}$ & $\begin{array}{l}\text { S/he can explain by giving } \\
\text { examples from daily life the effect } \\
\text { of surrounding climate on human } \\
\text { activities. }\end{array}$ & Spatial analysis \\
\hline & $\begin{array}{l}\text { Population and } \\
\text { settlement }\end{array}$ & $\begin{array}{l}\text { S/he can explain by giving } \\
\text { examples the effect of natural }\end{array}$ & $\begin{array}{l}\text { Spatial } \\
\text { description }\end{array}$ \\
\hline
\end{tabular}




\begin{tabular}{|c|c|c|c|}
\hline \multirow{3}{*}{$\begin{array}{l}\text { People, Places } \\
\text { and } \\
\text { Environments }\end{array}$} & & $\begin{array}{l}\text { features and human features in } \\
\text { and around the place lived on } \\
\text { population and settlement. }\end{array}$ & \\
\hline & $\begin{array}{l}\text { Disasters and } \\
\text { environmental } \\
\text { issues }\end{array}$ & $\begin{array}{l}\text { S/he can question formation } \\
\text { causes of disasters in the place } \\
\text { lived and causes of environmental } \\
\text { issues. }\end{array}$ & $\begin{array}{l}\text { Spatial } \\
\text { evaluation }\end{array}$ \\
\hline & $\begin{array}{l}\text { Effect of natural } \\
\text { disasters on our } \\
\text { lives }\end{array}$ & $\begin{array}{l}\text { S/he can explain by giving } \\
\text { examples the effect of natural } \\
\text { disasters on social life. }\end{array}$ & Spatial analysis \\
\hline $\begin{array}{l}\text { Production, } \\
\text { Distribution and } \\
\text { Consumption }\end{array}$ & $\begin{array}{l}\text { Economic } \\
\text { activities around } \\
\text { us }\end{array}$ & $\begin{array}{l}\text { S/he can analyze economic } \\
\text { activities in and around the place } \\
\text { lived. }\end{array}$ & Spatial analysis \\
\hline $\begin{array}{l}\text { Global } \\
\text { Connections }\end{array}$ & $\begin{array}{l}\text { Contribution of } \\
\text { residential place } \\
\text { to national } \\
\text { economy }\end{array}$ & $\begin{array}{l}\text { S/he can investigate the role of the } \\
\text { place lived in and its surrounding in } \\
\text { the economic relations with Turkey } \\
\text { and foreign countries. }\end{array}$ & Spatial analysis \\
\hline
\end{tabular}

Table 2 shows that the learning areas of Culture and Heritage, People, Places and Environments, Production, Distribution and Consumption and Global Connections involve certain spatial thinking skills. It was detected that 1 unit in the learning area of Culture and Heritage had an opportunity for students to gain spatial thinking skills and this was linked with spatial description. There were 5 units with acquisition opportunities in the learning area of People. Places and Environments learning and they are linked with spatial description, spatial analysis and spatial evaluation. There was 1 unit with an acquisition opportunity in the learning area of Production, Distribution and Consumption and Global Connections, and they were both linked with spatial analysis. It was also evidenced that spatial thinking skills were covered most in People, Places and Environments and all of the units of this learning area were linked with spatial thinking skills. However, there was no hierarchical structure for the acquisition and development of spatial thinking skills. The total number of units with acquisition opportunities related to spatial thinking skills were counted as 8; $3(37 \%)$ were matched with spatial description; $4(50 \%)$ were matched with spatial analysis; and $1(13 \%)$ was matched with spatial evaluation.

\section{Grade 5 Textbook: What Is the Distribution of Spatial Thinking Skills in Texts, Questions and Visuals of Units?}

In certain units of the BoE grade 5 social studies textbook, spatial thinking skills are evident. For the Culture and Heritage learning area, in the 'Learning Civilizations' unit, a map related to spatial description occurs. In this map the geographical position of Anatolia and Mesopotamia civilizations were given. 
Elbay, S. (2020). A Foundational Perspective for Spatial Thinking in Relation to Social Studies...

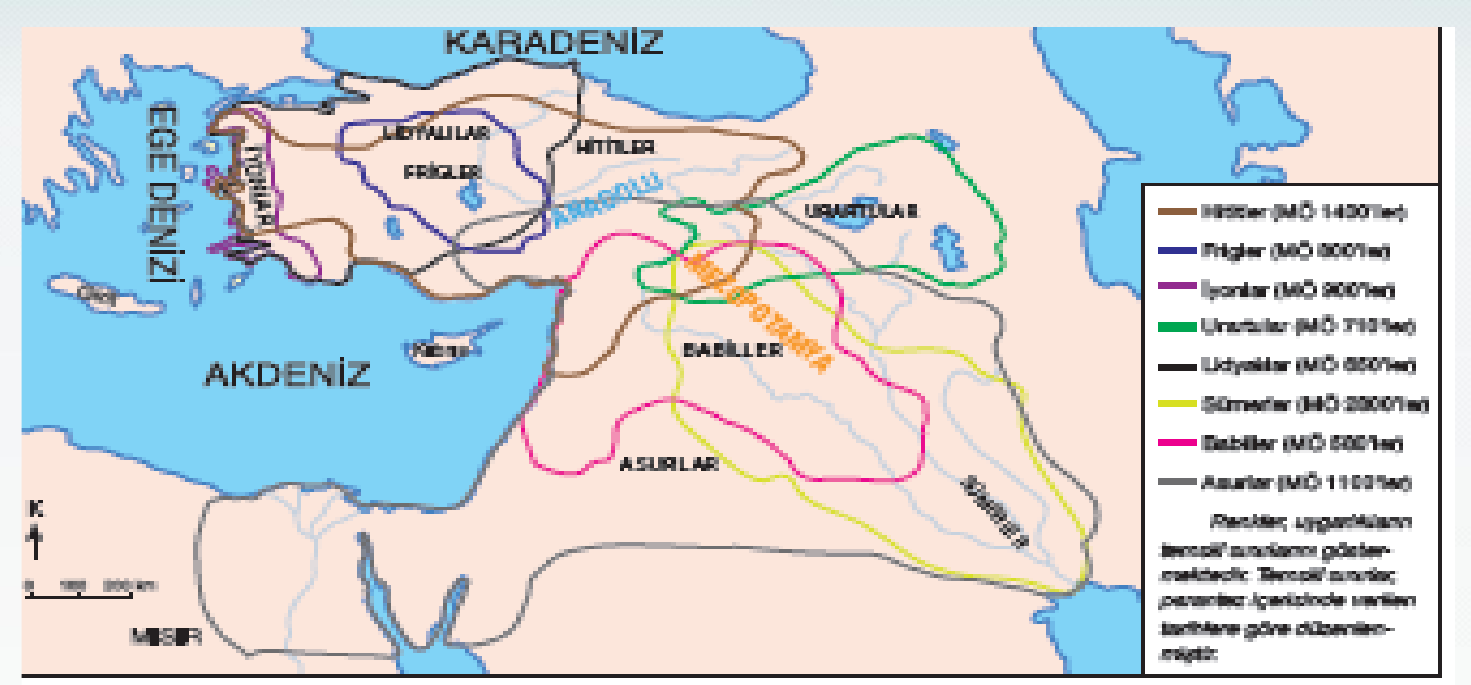

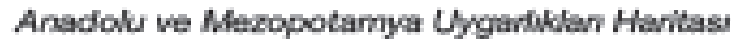

Figure 1. A model map for the spatial description in 5th grade social studies textbook (secondary school and Imam Hatip secondary school social studies 5th grade textbook, Şahin, 2018, p. 35).

Figure 1 in the grade 5 textbook illuminate's spatial relations about Anatolian and Mesopotamian civilizations. Hence, the positions of these civilizations between themselves according to continents and sea can be defined. For instance, it can be reasoned from the map that the Frigs existed to the south of the Lydians and east of the Aegean Sea. Building spatial relations in this way shows that the map activity is aimed spatial description.

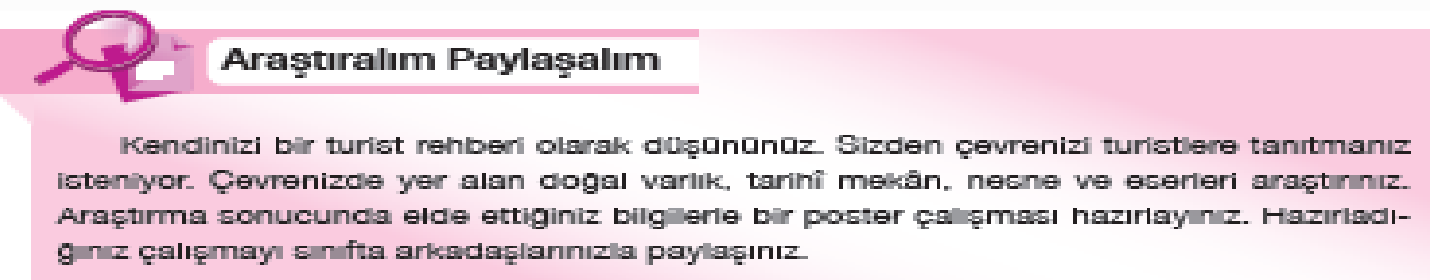

Figure 2. A research assignment for spatial description in the 5. grade social studies textbook (secondary school and Imam Hatip secondary school social studies 5th grade textbook, Şahin, 2018, p. 42).

In the unit 'Beauties Around' for the Culture and Heritage learning area, there is a research assignment on spatial description. The assignment is about collecting data on natural assets, historical places, objects and artifacts and describing the position of these places. Sample activities for the research show that these places were described by students. Within that context it can be argued that it was intended for students to gain spatial description skills. 


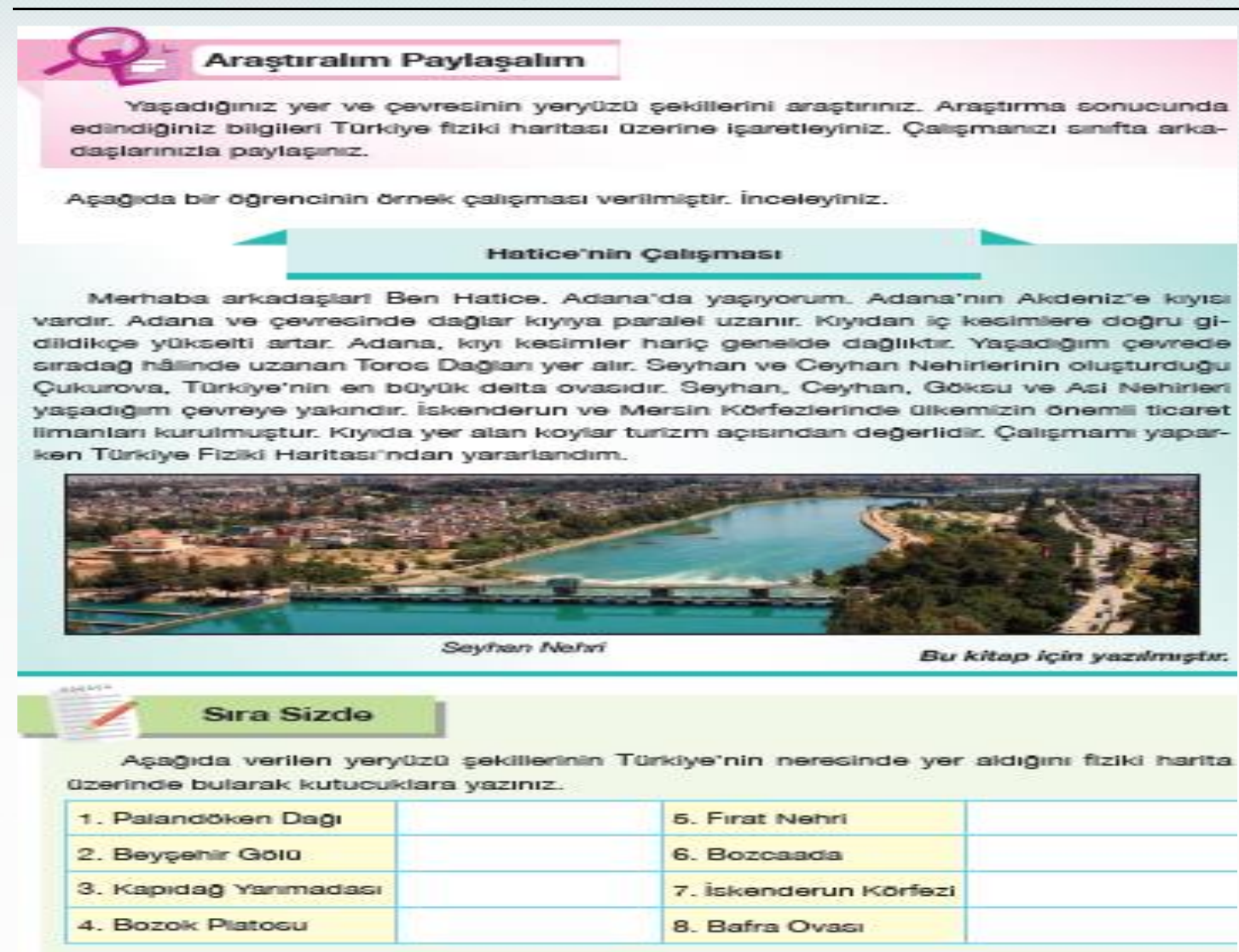

Figure 3. Texts and research assignment that integrates spatial description and analysis in the 5. grade social studies textbook (secondary school and Imam Hatip secondary school social studies 5th grade textbook, Şahin, 2018, p. 70).

In Figure 3 students are required to research and then share their assignments for a landform's unit in the learning area of People, Places and Environments. The texts and research assignment are linked with spatial description and analysis. The assignment is about collecting data on landforms. The sample activity for the assignment is, after giving a definition of landforms, demonstrating analytically from which points these forms are useful; thus, relations between landforms and spatial features are emphasized.

In the People, Places and Environments learning area there are other signs to support the acquisition and development of spatial thinking skills. For instance, in the unit 'Climate Effect on Human Activities' the questions show an attempt to develop spatial analysis skills because students are expected to draw a link in relation to place between climate and economic activities. The questions are: "How do climate features in your environment affect your daily activities?" and "How does climate affect the activities below (transportation, agriculture, residence-type and clothing)? Explain your opinions with supportive examples."

In the unit 'Population and Settlement' the research assignment can be linked with spatial evaluation because these tasks want students to make an evaluation based on the data about how residents of a place utilize geographical and human surroundings. The assignment is: "Based on the physical map in your book and population, analyze the effects of natural and human features on the population in your close environment. Share your findings with your classmates." 
Elbay, S. (2020). A Foundational Perspective for Spatial Thinking in Relation to Social Studies...

and "Write an example for the effects of natural and human features on the population and settlement in the table below."

In the unit 'Disasters and Environmental Issues', the question tests spatial evaluation skills as it requires students to offer appropriate measures for a given space in the face of likely natural disasters: "What should we do as a measure against the damages of natural disasters and environmental issues? Write your opinions by filling the blanks below." In the unit "Effects of Natural Disasters on Our Life', the question may be a sign of spatial analysis because in spatial analysis based on physical and population features as well as economic factors of an environment, a connection is set between events occurring in natural environment and human activities. The question is "Based on the articles on the newspaper how did the earthquake (flood, snow slide, landslide and forest fire) affect social life? Share your opinions with your classmates."

In the Production, Distribution and Consumption learning area under economic activities, the unit warm-up question is associated with spatial analysis: "How do people in and around where you live meet their needs? Share your ideas with class." To answer this question, students are required to analyze space in relation to performed economic-activity types. The following questions are related to spatial description and analysis: "search the economic activities in and around where you live. In your research, pay heeds to the geographical features of the place you live in and its surrounding. Share findings of your research in a poster. You can use visuals to enrich your poster assignment." and "below you can find some of the economic activities in Turkey. Please write next to each activity the kind of geographical feature that enables this activity" are the research assignments that indicate. For these questions' students are first required to gather data about a specific environment and then analyze the data to draw a connection between geographical factors and spatial features.

\section{Görseli Yorumlayalım}

Aફ̧agıdaki görsellerde verilen kişller hangi ekonomik faalyetlen yapmaktadır? Bu klşlierin yaptigi ekonomik faalyetler, sosyal hayatlanna nasıl etk etmektecir? Doşunceleriniż arkadạ̧larınızla paylą̧niz.
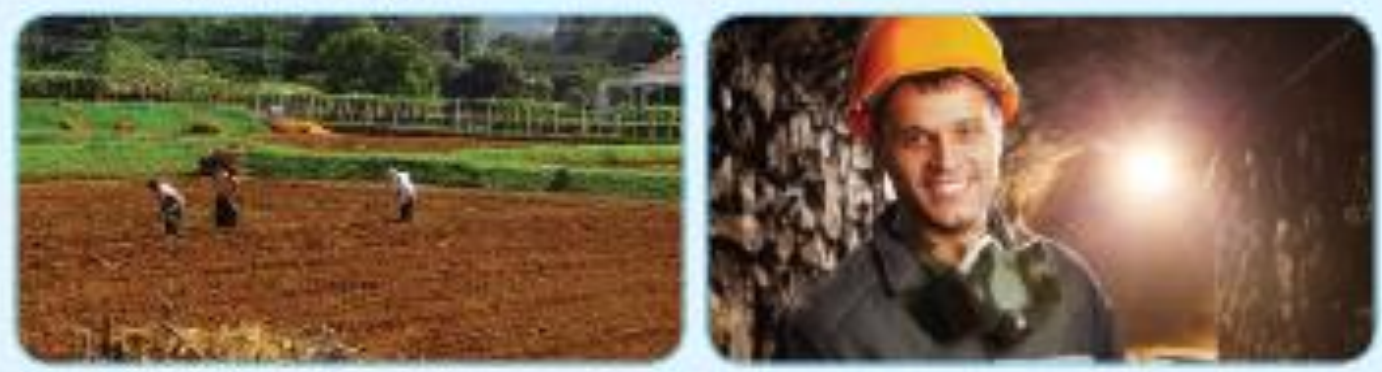

Figure 4. Economy and social life unit, a question about spatial analysis (secondary school and Imam Hatip secondary school social studies 5th grade textbook, Şahin, 2018, p. 132).

In Figure 4 the link between economic-activity types that change according to environmental conditions as well as economy and human activities is spatially focused and students are expected to answer the question based on making 
such a link. In the learning area of Global Connections, the unit 'Contribution of the Place I Live in to National Economy', has a question about spatial evaluation: "Search the role of the place you live in and its surrounding in the economic relations between Turkey and foreign countries. In the process of research pay heeds to the economic activities in the place you live in and its surrounding." The research assignment can be an opportunity for students to acquire and develop spatial evaluation skills. By using the expanding circle perspective, students are expected to make inferences about the skills of people in a certain environment of a geographical region. For the grade 5 social studies textbook, obtained findings about spatial thinking skills and they are collectively listed in table 3.

Table 3

Distribution of Spatial Thinking Skills in The Grade 5 Social Studies Textbook

\begin{tabular}{|c|c|c|}
\hline Learning area & Unit & Spatial skill \\
\hline \multirow[t]{3}{*}{ Culture and Heritage } & Learning civilizations & Spatial description \\
\hline & Beauties around & Spatial description \\
\hline & Landforms & $\begin{array}{l}\text { Spatial description and } \\
\text { analysis }\end{array}$ \\
\hline \multirow{5}{*}{$\begin{array}{l}\text { People, Places and } \\
\text { Environments }\end{array}$} & Climate effect on human activities & Spatial analysis \\
\hline & Population and settlement & Spatial evaluation \\
\hline & Disasters and environmental issues & Spatial evaluation \\
\hline & Natural disasters' effect on our life & \\
\hline & & Spatial analysis \\
\hline \multirow[t]{2}{*}{$\begin{array}{l}\text { Production, Distribution } \\
\text { and Consumption }\end{array}$} & Economic activities around us & $\begin{array}{l}\text { Spatial description and } \\
\text { analysis }\end{array}$ \\
\hline & Economy and social life & Spatial analysis \\
\hline Global Connections & $\begin{array}{l}\text { Contribution of the place I live in to } \\
\text { national economy }\end{array}$ & Spatial evaluation \\
\hline
\end{tabular}

As seen in table 3, the learning areas of Culture and Heritage, People, Places and Environments, Production, Distribution and Consumption and Global Connections are connected with certain spatial skills. All units in People, Places and Environments are connected to spatial thinking skills. There was 1 unit connected with spatial thinking skills in Global Connections. In the textbook there were 10 units connected to the acquisition of spatial thinking skills, and in these units, there were 4 (38\%) linked with spatial description; $5(48 \%)$ with spatial analysis, and 3 (14\%) with spatial evaluation.

\section{6th Grade; What Is the Distribution of Spatial Thinking Skills with Respect to Learning Area, Unit and Acquisitions?}

Table 4 exhibits spatial thinking skills listed in 6th grade Social Studies Curriculum.

Table 4

For Grade 6 Social Studies Curriculum; Distribution of Spatial Thinking Skills for Learning Area, Unit and Acquisitions

\begin{tabular}{lllll}
\hline Learning area & Unit & Acquisition & Spatial skill \\
\hline $\begin{array}{l}\text { Culture and } \\
\text { Heritage }\end{array}$ & $\begin{array}{l}\text { Turks in Sagas } \\
\text { and legends }\end{array}$ & $\begin{array}{l}\text { Makes inferences on the } \\
\text { geographical, Spatial description } \\
\text { economic and cultural features } \\
\text { of early Turkish states founded in } \\
\text { the Middle East. }\end{array}$ \\
& $\begin{array}{l}\text { Roads towards } \\
\text { Civilization }\end{array}$ & $\begin{array}{l}\text { Explains the role of ancient } \\
\text { trade roads for international }\end{array}$ & \\
\hline
\end{tabular}


Elbay, S. (2020). A Foundational Perspective for Spatial Thinking in Relation to Social Studies...

political, cultural and economic relations.

\begin{tabular}{|c|c|c|c|}
\hline & $\begin{array}{l}\text { My place on } \\
\text { Earth }\end{array}$ & $\begin{array}{l}\text { By using concepts on position, } \\
\text { s/he defines geographical } \\
\text { position of continents, oceans } \\
\text { and Turkey. }\end{array}$ & Spatial description \\
\hline & $\begin{array}{l}\text { Turkey's } \\
\text { beauties } \\
\text { map }\end{array}$ & $\begin{array}{l}\text { Based on Turkey's main } \\
\text { geographic features students } \\
\text { can analyze landforms, climate } \\
\text { features and vegetation on } \\
\text { relevant maps. }\end{array}$ & Spatial description \\
\hline $\begin{array}{l}\text { People, Places } \\
\text { and } \\
\text { Environments }\end{array}$ & $\begin{array}{l}\text { Turkey's } \\
\text { beauties on } \\
\text { map } \\
\text { Our neighbors }\end{array}$ & $\begin{array}{l}\text { Students can show Turkey's } \\
\text { main human-geographic } \\
\text { features on relevant maps. } \\
\text { Based on people's lives in } \\
\text { different natural environments } \\
\text { on Earth students can make } \\
\text { inferences on climate features. }\end{array}$ & $\begin{array}{l}\text { Spatial description } \\
\text { Spatial analysis }\end{array}$ \\
\hline $\begin{array}{l}\text { Production, } \\
\text { Distribution and } \\
\text { Consumption }\end{array}$ & $\begin{array}{l}\text { I have } \\
\text { Project }\end{array}$ & $\begin{array}{l}\text { Based on Turkey's geographical } \\
\text { features students can provide } \\
\text { project suggestions for } \\
\text { investment and marketing. }\end{array}$ & Spatial evaluation \\
\hline
\end{tabular}

Table 4 shows that the learning areas of Culture and Heritage, People, Places and Environments and Production, Distribution and Consumption involve certain spatial thinking skills. There are 2 units which provide the opportunity for students to acquire and develop spatial thinking skills under Culture and Heritage, are they are connected with spatial description and spatial evaluation, there are 4 units in People, Places and Environments which are connected with spatial description and spatial analysis. There is 1 unit in Production, Distribution and Consumption which is linked with spatial evaluation. Also, as reported, the opportunity to acquire and develop spatial thinking skills are most widely covered in the learning area of People, Places and Environments although all units of this learning area are connected with spatial thinking skills. Also, it can be argued that in this learning area there is a hierarchal structure for the acquisition of spatial thinking skills. There were 7 acquisition opportunities connected with spatial thinking skills: 4 (57\%) of which were matched with spatial description: 1 (14\%) was linked with spatial analysis; and 2 (29\%) were linked with spatial evaluation.

\section{Grade 6 Textbook: What Is the Distribution of Spatial Thinking Skills in Texts, Questions and Visuals of Units?}

In the Culture and Heritage learning area, the 'Turks in Sagas and Legends' unit in the BoE grade 6 social studies textbook, there is a question connected with spatial description: "Based on the data below, draw the borders of Central Asia on Asian physical map.". For this question students are expected to describe Central Asia's land position and consequential geographic - position data. Additionally, as for the space description question "Based on Ergenekon saga, what do you think about the geographical features of the place Early Turks lived in?" It is hoped students will make the connection between space and 
environmental features. Also, the presence of maps in all of the units is a sign of spatial description.

\section{- Günlük hayatta kullanılan cep telefonu ve navigasyon gibi elektronik cihazlar, bir ye- rin konumunu belirlemede ve adresini bulmada hangi verilerden faydalaniyor olabi- lir? Tartışınız.}

\section{SIra Sizde okul servisi, Ali'nin evine uğradıktan sonra öğrencileri bırakmak için okula gide cektir. Servis şoförüne yön bilgilerini kullanarak yolu tarif ediniz?}

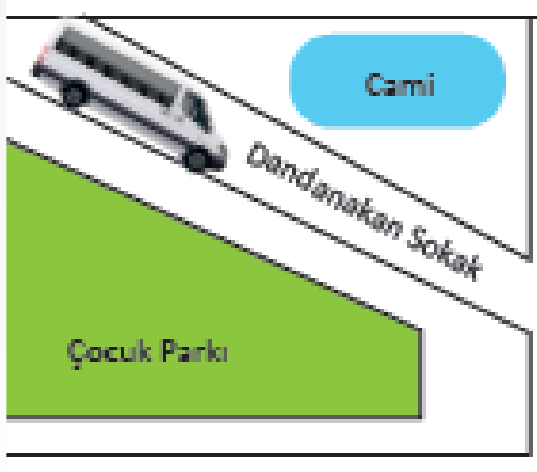

Miryolkefalon Sokak

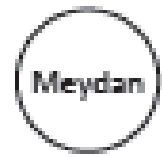

Deviet Hastanesi

Ecdat Caddesi

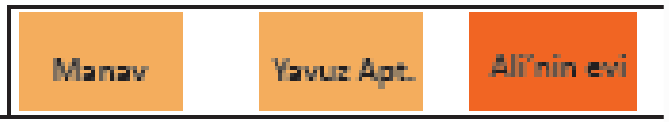

Figure 5. In People, Places and Environments learning area, in 'My Place on Earth' unit, questions which are about spatial description (secondary school and Imam Hatip secondary school social studies 6th grade textbook, Ylmaz, Bayraktar, Özden, Akpınar and Evin, 2018, p. 94).

Figure 5 (above-listed questions) aims to reveal the students' skills at interpreting design directions and space. Connecting these skills with places in everyday life is indicative of spatial description and in the same unit there are texts and questions which test the student positional knowledge.

In 'Turkey's Beauties on Map' unit, some texts and questions were about spatial description and spatial analysis. The following question requires students to recognize a place and provide its spatial description: "Below are visuals and definitions of landforms. Fill in the blanks with the names of pictured landforms (cove, island, plains, mountain, cape, delta plains, peninsula, lake, plateau, and stream)". As for spatial analysis the following questions are stated in the textbook thus students are expected to make a connection between elevation and economic \& social life: "If Turkey's average elevation level was below Asia and Europe continents, how our lives would change?" and "If, in Turkey, mountains lined from northern to southern direction how would the climate in our place change?"

In 'Turkey's Beauties on Map' unit, some texts and questions signaled spatial analysis. For example, the following questions require students to connect physical, population and economic features with human activities thus such questions can be linked with spatial analysis: "If you had a chance to build and 
Elbay, S. (2020). A Foundational Perspective for Spatial Thinking in Relation to Social Studies...

operate finance facilities below, in which Turkish city you would build the facility based on the data given on the map? Please discuss. Write on the map below and indicate its position." and "Analyze Turkey physical map below and fill in the blanks with proper examples for the physical, geographical and human features of corresponding places".

In 'Our Neighbors' unit, the following questions demand students analyze the link between spatial features and environment: "Although people living in the southern coastal regions of Turkey feel no need to use winter tire, people in inland need it. What may be the reasons?" and "In the below-images there are two settlements, why do you think houses are painted in different colors?" Also, in the same unit the following questions emphasize spatial evaluation because the questions are about measures to take against natural disasters in a given geographical environment: "Are there any floods or similar natural disasters in your place? What kind of measures should be taken against floods?"

In the Production, Distribution and Consumption learning area under 'Save the World' unit, there are questions which are indicative of spatial evaluation: "Recently there has been a rise in industrial facilities in Şanlıurfa. How is it possible to meet energy needs of these industrial facilities without harming the nature?" and "The table below displays causes of natural problems and effects of these problems on human lives. Fill in the blanks with proper statements as given in the examples." To respond to this question, students are required to use spatial evaluation skills to search how people can benefit from the nature without harming natural environment.

In 'I Have a Project' unit, certain texts and questions signaled spatial evaluation. For example, the following questions demand students make a connection between economic conditions and spatial preferences by taking environmental features into account: "While devising investment or marketing projects which features of a city or region should be accounted?" and "What are the geographical, historical and cultural features of the city or region you live in? Fill in the blanks below and prepare an investment or development project that matches with these features."

In the textbook, research findings that relate to opportunities for students to acquire and develop spatial thinking skill are cumulatively listed in table 5.

Table 5

Distribution of Spatial Thinking Skills in The Grade 6 Social Studies Textbook

\begin{tabular}{|c|c|c|c|}
\hline Learning area & Unit & Spatial skill & \\
\hline Culture and Heritage & $\begin{array}{l}\text { Turks in Sagas and legends } \\
\text { Other units }\end{array}$ & $\begin{array}{l}\text { Spatial description } \\
\text { Spatial description }\end{array}$ & \\
\hline $\begin{array}{l}\text { People, Places and } \\
\text { Environments }\end{array}$ & $\begin{array}{l}\text { My place on Earth } \\
\text { Turkey's beauties on map } \\
\text { Turkey's beauties on map } \\
\text { Our neighbors }\end{array}$ & $\begin{array}{l}\text { Spatial description } \\
\text { Spatial description } \\
\text { analysis } \\
\text { Spatial analysis } \\
\text { Spatial analysis } \\
\text { evaluation }\end{array}$ & $\begin{array}{l}\text { and } \\
\text { and }\end{array}$ \\
\hline $\begin{array}{l}\text { Production, Distribution } \\
\text { and Consumption }\end{array}$ & $\begin{array}{l}\text { Economic activities around us } \\
\text { Economy and social life }\end{array}$ & $\begin{array}{l}\text { Spatial description } \\
\text { analysis } \\
\text { Spatial analysis }\end{array}$ & and \\
\hline Global Connections & $\begin{array}{l}\text { Save the world } \\
\text { I have a Project }\end{array}$ & $\begin{array}{l}\text { Spatial evaluation } \\
\text { Spatial evaluation }\end{array}$ & \\
\hline
\end{tabular}


As shown in table 5 the learning areas of Culture and Heritage, People, Places and Environments, Production, Distribution and Consumption and Global Connections are related with certain spatial thinking skills. Also, all units of Culture and Heritage and People, Places and Environments are related to spatial thinking skills. In the textbook, 10 units were associated with spatial thinking skills. Among these units, 4 (38\%) were linked with spatial description, 5 (48\%) were linked with spatial analysis and 3 were linked with (14\%) spatial evaluation.

\section{Grade 7: What Is the Distribution of Spatial Thinking Skills with Respect to Learning Area, Unit and Acquisitions?}

Table 6 exhibits the spatial thinking skills evident in the $7^{\text {th }}$ grade Social Studies Curriculum.

Table 6

For Grade 7 Social Studies Curriculum; Distribution of Spatial Thinking Skills for Learning Area, Unit and Acquisitions

\begin{tabular}{|c|c|c|c|}
\hline Learning area & Unit & Acquisition & Spatial skill \\
\hline \multirow{4}{*}{$\begin{array}{l}\text { People, Places and } \\
\text { Environments }\end{array}$} & Where to settle & $\begin{array}{l}\text { Via case analyses, making } \\
\text { inferences on the factors } \\
\text { that affected settlement } \\
\text { choices from the past till } \\
\text { now. }\end{array}$ & $\begin{array}{l}\text { Spatial } \\
\text { evaluation }\end{array}$ \\
\hline & $\begin{array}{l}\text { Turkey on tables and } \\
\text { graphs }\end{array}$ & $\begin{array}{l}\text { Based on the factors } \\
\text { effective on the population }\end{array}$ & Spatial analysis \\
\hline & & $\begin{array}{l}\text { distribution in Turkey, } \\
\text { making interpretations on } \\
\text { Turkey's demographic } \\
\text { features. }\end{array}$ & \\
\hline & $\begin{array}{l}\text { Where I was born or } \\
\text { where I work? Which } \\
\text { one is my home! }\end{array}$ & $\begin{array}{l}\text { Through case studies } \\
\text { students can discuss the } \\
\text { causes and effects of } \\
\text { migration. }\end{array}$ & Spatial analysis \\
\hline
\end{tabular}

Table 6 indicates that certain spatial thinking skills occur in the People, Places and Environments learning area. It emerged that 3 units provide opportunities for students to acquire and develop spatial thinking skills in People, Places and Environments in the category of spatial analysis and spatial evaluation. In the People, Places and Environments learning area, out of a total of 4 units and opportunities for students to acquire and develop spatial thinking skills, 3 are linked with spatial thinking skills and there is no hierarchal structure evident among the spatial thinking skills. From the 3 units which provided opportunities for students to acquire spatial thinking skills, 2 (62\%) were linked with spatial analysis, while $1(38 \%)$ was linked with spatial evaluation.

\section{Grade 7 Textbook: What Is the Distribution of Spatial Thinking Skills in Texts, Questions and Visuals of Units?}

In the Culture and Heritage learning area section of the BoE-designed grade 7 social studies textbook, the unit 'From Tribes to World Empire' has a question about spatial analysis: "Which contributions can the geography of a state offer to the nation?". The question expects students to make a connection between economic, political \& social features and space. The visuals in the "Europe Awakening' unit signaled the inclusion of spatial description. 
Elbay, S. (2020). A Foundational Perspective for Spatial Thinking in Relation to Social Studies...

In the People, Places and Environments learning area, the 'Where to Settle' unit involved a question linked with spatial analysis. Within that context photos were shown in relation to the question "Please read the information on Sicily and Cappadocia. Write down the reasons for choosing these places as settlement in the blanks below." This is a question that requires students to draw a connection between spatial features and human activities. In the same unit, there is a spatial description statement which aims to encourage students to unveil some spatial features of place: "Below are photos that show features of different settlements. By analyzing photos and conversations note the natural and human features of these places as seen in the sample."

In the Global Connections learning area, a question indicative of spatial evaluation is evident in the 'I Find Solutions for Global Problems' unit: "Form teams with your classmates. Choose one of these global problems (Global climate change, natural disasters, hunger, terrorism, migration) and write below your suggested solutions for this global issue". The question wants students to devise measures against the negative effects of natural, geographical and human factors on human life. In the textbook, research findings that relate to the opportunities for students to acquire spatial thinking skills are cumulatively displayed in table 7.

Table 7

For Grade 7 Social Studies Textbook; Distribution of Spatial Thinking Skills

\begin{tabular}{lll}
\hline Learning area & Unit & Spatial skill \\
\hline Culture and Heritage & $\begin{array}{l}\text { From tribes to World Empire } \\
\text { Europe awakening }\end{array}$ & $\begin{array}{l}\text { Spatial analysis } \\
\text { Spatial description }\end{array}$ \\
$\begin{array}{l}\text { People, Places and } \\
\text { Environments }\end{array}$ & Where to settle & $\begin{array}{l}\text { Spatial description } \\
\text { analysis }\end{array}$ \\
\hline Global Connections & I find solutions for global problems & \begin{tabular}{l} 
Spatial evaluation \\
\hline
\end{tabular}
\end{tabular}

Table 7 shows that learning areas of Culture and Heritage, People, Places and Environments and Global Connections are associated with certain spatial skills. In the Culture and Heritage learning area it was 2 units; and in the learning areas of People, Places and Environments and Global Connections it was 1 unit that was linked with spatial thinking skills. Furthermore, in the textbook, 4 units were reported to be linked with spatial thinking skills. Among these units 2 (37\%), were linked with spatial description 2 (37\%) were linked with spatial analysis, and 1 $(26 \%)$ was linked with spatial evaluation.

Taking all of these findings into consideration, some conclusions were reached regarding the distribution of spatial thinking skills in the 2018 Middle School Social Studies Curriculum and BoE secondary school textbooks. In the $5^{\text {th }}$ grade the total number of opportunities for students to acquire and develop spatial thinking skills is $8(40 \%)$, and the total number of units in the related textbook is 12 (60\%). In the $6^{\text {th }}$ grade, the total number of opportunities for students to acquire and develop spatial thinking skills is 7 (37\%), total number of units in the relevant textbook is 12 (63\%). In the $7^{\text {th }}$ grade, the total number of opportunities for students to acquire and develop spatial thinking skills is $3(37 \%)$, and total number of units in the relevant textbook is 5 (63\%). It has also been identified that the total number of acquisition opportunities for spatial description is $7(41 \%)$ and total number of units in the relevant textbook is $10(59 \%)$. Also, the total number of acquisition opportunities for spatial analysis is $7(37 \%)$, and the total number of units in the 
relevant textbook is 12 (63\%). Finally, the total number of acquisition opportunities for spatial evaluation is $4(36 \%)$ and the total number of units in the relevant textbook is 7 (64\%). As a result, it was found that the total number of opportunities for students to acquire and develop spatial thinking skills was 18 while the total number of units in the relevant textbook was 29.

\section{Conclusion and Discussion}

The current study aimed to unveil how spatial thinking skills were mirrored in Social Studies Curriculum and associated textbooks. The study also aimed to see whether or not student acquisition of spatial thinking skills was coordinated with the texts, visuals and questions evident in textbooks. Thus, the study revealed how spatial thinking skills are reflected in curriculum and textbooks.

Research findings suggest that the spatial thinking skills of students at 5th grade level were associated with the following learning areas: Culture and Heritage; People, Places and Environments; Production, Consumption and Distribution; and Global Connections. Similarly, the spatial thinking skills of students at 6th grade level were also associated with the learning areas of Culture and Heritage; People, Places and Environments; and Production, Consumption and Distribution. By the time students are in 7th grade their spatial thinking skills are associated only with the learning area of People, Places and Environments.

On the other hand, Aydemir (2017) reports slighty different findings to those emerging from the current study. For example, it is at 6th grade level (rather than 5th grade level) that the spatial perception skills acquired by students are related to the learning areas of Culture and Heritage; People, Places and Environments; Production, Consumption and Distribution; and Global Connections. By the time students have reached 7th grade level Aydemir (2017) reports that spatial perception skills acquired by students are related to the learning areas of Culture and Heritage; People, Places and Environments; Production, Consumption and Distribution.

It was evident from the current research that student acquisition of spatial thinking skills occurred mostly during the $5^{\text {th }}$ and $6^{\text {th }}$ grades of schooling, whereas such skill acquisition occurred at a comparatively minimal level during the $7^{\text {th }}$ grade of schooling. Likewise, a study by Uğurlu and Aladağ (2015) also detected the acquisitions of spatial thinking skills were mostly gained by students during the $5^{\text {th }}$ and $6^{\text {th }}$ grades of schooling and the lowest rates of skills acquisition occurred in the 7th grade.

Research findings from the Active Citizenship learning area, revealed no evidence of spatial thinking skills being acquired from the texts, visuals, and questions used in textbooks or from the curriculum. Likewise, in the study of Aydemir (2017) spatial thinking skills were not seen in BoE-designed textbooks for the Active Citizenship learning area. As opposed to that, in the study by Karasu, AvCl and Faiz (2018), in the learning area of Active Citizenship the skills of spatial perception existed in the 5th-grade Social Studies textbook.

According to the results of this study, the learning areas of the Social Studies Curriculum which are closely associated with spatial thinking skills are firstly People, Places and Environments, followed by Culture and Heritage, then Production, Consumption and Distribution, and then Global Connections. As 
Elbay, S. (2020). A Foundational Perspective for Spatial Thinking in Relation to Social Studies...

opposed to this in Social Studies Curriculum, it is focused on Culture and Heritage learning area which should be assessed in conjunction with historical literacy skills (MoNE, 2018). The acquisitions of spatial perception skills in the learning area of Culture and Heritage was not among the skills available for students to acquire. On the other hand, in the study of Tversky (1993), it was shown that even historical conquests were useful to draw conclusions on about spaces and in this way spatial thinking could be developed.

In Social Studies Curriculum it is believed that the spatial thinking skills to be initially acquired by students are spatial description and spatial analysis because current research findings show these two areas form $78 \%$ of spatial thinking skills. Such a finding is similar to the spatial concepts' distribution in the Canadian National Geography Curriculum which reveals that locational-info acquisition is prioritized (Huynh and Sharpe, 2012). The research finding from the current study can also be seen as consistent with spatial thinking perceptions of social studies teachers. That is because teachers defined spatial thinking in general as students' ability to recognize close environment first and then interactions with the natural environment. (Uğurlu \& Aladağ, 2015). On the other hand, in Öcal's (2007) study it was revealed that students failed to sufficiently describe close environments but Madsen and Rump (2013) viewed spatial analysis as a must-have skill for solving spatial problems.

Findings posit that there is not a hierarchical structure among spatial thinking skills. Within that context, as for opportunities for students to acquire and develop spatial thinking skills, in grade 5 the focus was on spatial analysis but in grades 6 and 7 spatial evaluation dominated. However, spatial perception and spatial description in the younger ages could enable students to acquire spatial analysis and spatial evaluation skills consecutively. In the same vein the research of Örnkloo (2007) pointed that, 20-month old children had difficulty in setting the direction of objects while 30-month old children could set the direction of objects and 40-month old children could differentiate between dimensions and shapes, hence the study proved that spatial thinking could possess a hierarchal structuring as well.

The research findings highlight a few priorities for further consideration. Firstly, it can be argued that the distribution of texts, visuals and questions about spatial thinking skills in the textbooks are not coordinated with the distribution of student acquisition of spatial thinking skills. Since the acquisition in the curriculum should be reflected in the textbooks, it may be necessary to establish a relationship between the textbooks and the curriculum. Because the acquisitions are included in the curriculum to create the desired behavior change in students. Failure to reflect the acquisition in the curriculum to the textbooks may result in the learning outcomes not as desired. Moreover, in regard to spatial thinking there could be a gap between student acquisition of spatial thinking skills and coverage of such skills in the textbooks because skill acquisition occurs through the in-class activities developed by the teacher. However, research already shows that teachers fail to offer visual-mind activities to effectuate spatial thinking skills, and in general have a teaching practice that prioritizes spatial description (Uğurlu and Aladağ, 2015). As a second conclusion it can be claimed that there is not a hierarchy between grade levels as for the acquisition of spatial thinking skills and this could be a challenge for instilling complex spatial thinking 
skills in student minds. Likewise, Gagne (1988) argues that cognitive learning experiences have a hierarchal structure. Thirdly it is attested that texts, visuals and questions in textbooks are not appropriate ways to teach students about the concepts of spatial thinking. For instance, prepositions of place (in front of, behind, on the right, on the left etc.), that are the most featured concepts for directions, were absent in the textbooks to exemplify correct and incorrect case situations.

Based on findings from the current study, the suggestions for further development of spatial thinking skills in social studies are;

$>$ In the Social Studies Curriculum, the inclusion of spatial thinking skills should follow a hierarchal structure from simple to complex,

> For the Middle-School Social Studies textbooks, the texts, visuals and questions about spatial thinking skills should be coordinated with the grade levels and learning areas associated with student acquisition of spatial thinking skills,

> For the Middle-School Social Studies textbooks, students' responses to exercises and questions about spatial thinking skills should be analyzed in accordance with the grade levels and learning areas associated with student acquisition of spatial thinking skills,

> Further studies should be conducted to improve spatial analysis skills and the evaluation of spatial rotation.

\section{References}

Aydemir, M. (2017). Examination of middle school social sciences text books in terms of skills included in the middle school social sciences course curriculum. International Journal of Contemporary Educational Studies, 3(2), 1-17.

Baloğlu Uğurlu, N., \& Aladağ, E. (2015). The placing of spatial thinking in Turkish social studies education and social studies teachers' opinion about this issue. Marmara Geographical Review, 35, 22-42.

Bednarz, S. W. (2007). Proceedings in changing geographies: Innovative curricula. In S. Catling \& L. Taylor (Eds.), mapping the way forward in an uncertain world: Spatial thinking and Geography (pp. 13-28). London: Institute of Education, University of London

Behrmann, M., Geng, J. J., \& Shomstein, S. (2004). Parietal cortex and attention. Current Opinion in Neurobiology, 14, 212-217.

Carroll, J. B. (1993). Human cognitive abilities: A survey of factor-analytic studies. Cambridge University Press.

Cohen, M. S., Kosslyn, S. M., Breiter, H. C., DiGirolamo, G. J., Thompson, W. L., Anderson, A. K., et al. (1996). Changes in cortical activity during mental rotation: A mapping study using functional MRI. Brain, 119, 89-100.

Coolican, H. (2009). Research methods and statistics Psychology (5nd ed.). London: Hodder Education.

Creswell, J. W. (2013). Qualitative inquiry \& research design choosing among five approaches (3nd ed.). USA: Sage.

Education Information Network (EIN), (2018). Secondary school social studies 5, 6 and 7th grade textbooks. http://www.eba.gov.tr/ekitap? channel=8. 
Elbay, S. (2020). A Foundational Perspective for Spatial Thinking in Relation to Social Studies...

Epstein, R. A., Patai, E. Z., Julian, J. B., \& Spiers, H. J. (2017). The cognitive map in humans: Spatial navigation and beyond. Nature Neuroscience, 20, 1504-1513.

Feng, J., Spence I., \& Pratt, J. (2007). Playing an action video game reduces gender differences in spatial cognition. Psychological Science, 18(10), 850-855.

Gagne, R. M. (1988). The Conditions of Learning. New York: Holt Reinhart and Winston.

Gardner, H. (1983). Frames of Mind: The Theory of Multiple Intelligences. New York: Basic Books.

Glesne, C., \& Peshkin, A. (1992). Becoming qualitative researchers an introduction. London: Longman Group Ltd.

Golledge, R. G., \& Stimson, R. J. (1997). Spatial Behavior: A Geographic Perspective. New York: Guilford Press.

Huynh, N. T., \& Sharpe, B. (2013). An assessment instrument to measure geospatialthinking expertise. Journal of Geography, 112(1), 3-17.

Karasar, N. (2017). Scientific research method: concepts, principles, techniques (32nd ed.). Ankara: Nobel.

Karasu Avcl, E., \& Faiz, M. (2018). Examining the skills and values in the "Effective Citizenship" learning domain of 4th and 5th grade social studies textbooks. International Journal of New Approaches in Social Studies (IJONASS), 2(1), 1-21.

Kitchin, R. M., \& Freundschuh, S. (2000). Cognitive mapping: Past, present, and future. London and New York: Routledge.

Kitchin, R. M., \& Freundschuh, S. (2018). Cognitive mapping: Past, present and future. London and New York: Routledge Taylor \& Francis Group.

Levine, S. C., Huttenlocher, J., Taylor, A., \& Langrock, A. (1999). Early sex differences in spatial skill. Developmental Psychology, 35(4), 940-949.

Lincoln, Y. S., \& Guba, E. G. (1985). Naturalistic inquiry. Newbury Park, CA: Sage.

Lohman, D. F. (1996). Spatial ability and g. In I. Dennis \& P. Tapsfield (Eds.), Human abilities: Their nature and measurement (p. 97-116). Lawrence Erlbaum Associates, Inc.

Madsen, L. M., \& Rump C. (2012). "Considerations of how to study learning processes when students use GIS as an instrument for developing spatial thinking skills" Journal of Geography in Higher Education, 36(1), 97-1 16.

Maxwell, J. A. (1992). Understanding and validity in qualitative research. Harvard Educational Review, 62 (3), 279-300.

McGee, M. G. (1979). Human spatial abilities: Psychometric studies and environmental, genetic, hormonal, and neurological influences. Psychological Bulletin, 86, 889-918.

Merç, A. (2011). Spatial cognition and map-reading skills of students studying social studies education and pre-school education (Unpublished Mastery Thesis). Adnan Menderes Universty, Institute of Social Science, Aydın.

Miles, M. B., \& Huberman, M. A. (1994). An expanded source-book qualitative data analysis. London: Sage.

Ministry of National Education (MoNE), (2018). Secondary education Geography lesson (9th, 10th, 11th and 12th grades) curriculum. Ankara. http://mufredat.meb.gov.tr.

Ministry of National Education (MoNE), (2018). Social studies curriculum (primary and secondary schools 4, 5, 6 and 7 grades). Ankara. http://mufredat.meb.gov.tr.

Mutluer, C. (2013). The views of social studies teachers about the skills contained in social studies (the example of İmir Menemen). Turkish Studies, 8(7), 355-362. 
National Curriculum Standards for Social Studies (NCSS), (2014). The themes of Social Studies published on National Council for the Social Studies (http://www.socialstudies.org).

National Research Council (NRC), (2006). Learning to think spatially: GIS as a support system in the K-12 curriculum. Washington, DC: The National Academies Press.

Newcombe, N. S. (2010). Picture This: Increasing Math and Science Learning by Improving Spatial Thinking. American Educator, 34 (2), 29-36.

Newcombe, N., \& Huttenlocher, J. (2000). Making space: The development of spatial representation and reasoning. Cambridge, Mass.: MIT Press.

Öcal, A. (2007). The study of spatial cognition skills of 6th grade students in Primary Education Social Studies course (Unpublished Doctoral Thesis). Gazi University, Institute of Education, Ankara.

Öcal, A. (2014). New approaches in teaching social studies-1 in Turan, R., Sünbül, A.M. and Akdağ, H. (Eds.), rethinking the ability to perceive space in the Social Studies course (pp. 263-278). Ankara: Pegem Academi.

Örnkloo, H. (2007). Fitting objects into holes. On the development of spatial cognition skills. Acta Universitatis Upsaliensis. Digital Comprehensive Summaries of Uppsala Dissertations from the Faculty of Social Sciences 34.84 pp. Uppsala.

Patton, M. Q. (2014). Qualitative research and evaluation methods. Mesut Bütün, Selçuk Beşir Demir (Trans. Ed.), Translation from 3rd Edition, Ankara: Pegem Academy.

Pehlivan, A., \& Kolaç, E. (2016). Elements of the ich in open-formal education social studies textbooks and curriculum. Turkish Studies, 11 (19), 655-670.

Pellegrino, J. W., Alderton, D. L., \& Shute, V. J. (1984). Understanding spatial ability. Educational Psychologist, 19(4), 239-253.

Roberts, P., \& Priest, H. (2006). Reliability and validity in research. Nursing Standard, 20, 4145.

Safi, H. (2010). Teachers' views on the development of the perception skill in the social studies curriculum (Unpublished Mastery Thesis). Marmara University, Institute of Education, ìstanbul.

Şahin, E. (2018). Secondary school and imam hatip secondary school social studies 5th grade textbook. Ankara: Anadol.

Schultz, R.B., Kerski, J.J. \& Patterson, T.C. (2008). The Use of Virtual Globes as a Spatial Teaching Tool with Suggestions for Metadata Standards. Journal of Geography, 107(1), 27-34.

Shemyakin, F. N. (1962). Orientation in space. In Psychological Science in the USSR. B.G. Ananyev et al. (Eds). (Vol. 1), pp. 186-255. Washington: U.S. Office of Tech. Services (No. 11466).

Spence, I., \& Feng, J. (2010). Video games and spatial cognition. Review of General Psychology, 14(2), 92-104.

Taş, A. M. (2007). Determination of teachers' views on new social studies textbooks. Selçuk University Journal of Social Sciences Institute, 1 (17), 519-532.

Tversky, B. (1993). Cognitive maps, cognitive collages, and spatial mental models. In Frank, A.U. and Campari, I. (Eds.) Spatial Information Theory: A Theoretical Basis for GIS, Proceedings COSIT '93. Lecture Notes in Computer Science, 716, pp.14-24, Springer: Berlin.

Ünlü, M., \& Yıldırım, S. (2017). A geographical skill suggestion to geography teaching curriculum: Spatial thinking skill. Marmara Geographical Review, 35, 13-20. 
Elbay, S. (2020). A Foundational Perspective for Spatial Thinking in Relation to Social Studies...

Yıldırım, A., \& Şimşek, H. (2013). Qualitative research methods in the social sciences. Ankara: Seçkin.

Yılmaz, F. K., Bayraktar, H., Özden, M. K., Akpınar, M., \& Evin, Ö. (2018). Secondary school and imam hatip secondary school social studies 6th grade textbook. Ankara: MONE.

\section{Annex 1}

Spatial Thinking Skills Analysis List for Acquisition in The Social Studies Curriculum (5th Grade Example)

\begin{tabular}{|c|c|c|c|c|c|c|c|c|c|}
\hline \multirow[b]{2}{*}{ 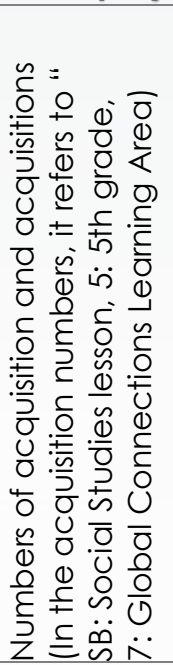 } & \multicolumn{3}{|c|}{ Spatial description } & \multicolumn{3}{|c|}{ Spatial analysis } & \multicolumn{3}{|c|}{$\begin{array}{l}\text { Spatial } \\
\text { evaluation }\end{array}$} \\
\hline & 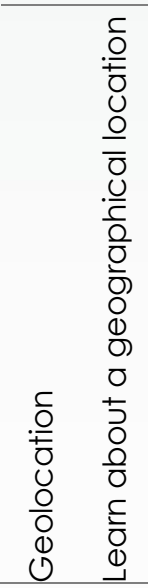 & 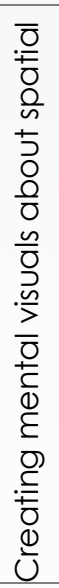 & 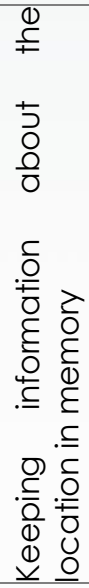 & 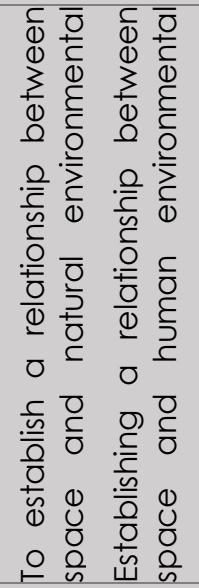 & 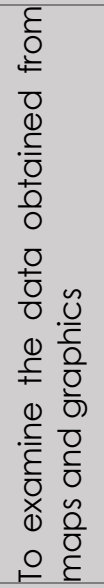 & 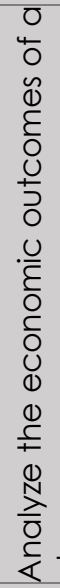 & 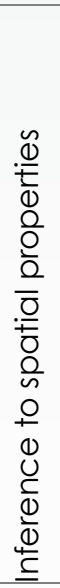 & 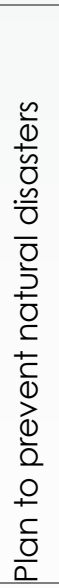 & 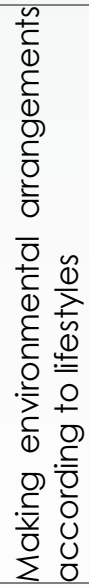 \\
\hline
\end{tabular}

SB.5.1.1. Of Social

Studies, as an

active citizen of the

Republic of Turkey

recognizes the

contribution to its

development.

SB.5.1.2. It explains

the multi-

dimensionality of an

event based on an

example in its

immediate vicinity.

SB.5.1.3. Acts in

accordance with

the duties and

responsibilities

required by the

roles in the groups

he / she

participates as an

individual who is

aware of his rights.

SB.5.1.4. It gives

examples of

exercising their

rights as children

and situations

where these rights

are violated.

SB.5.2.1. Based on

its concrete 
remnants, it

recognizes the

important

contributions of

Anatolian and

Mesopotamian

civilizations to

human history.

SB.5.2.2. It

introduces natural

sites, historical

places, objects and

artifacts.

SB.5.2.3. Identifies

similar and different

elements between

them by comparing

the cultural

characteristics of

the various parts of

our country with the

cultural

characteristics of

the environment in

which they live.

SB.5.2.4. Analyzes

the role of cultural

elements in

coexistence.

SB.5.2.5. Evaluates

the historical

development of

cultural elements in

daily life.

SB.5.3.1. Describes

the landforms of the

place where he

lives on and on the

maps in general.

SB.5.3.2. Explains the

effect of the

climate seen in the

environment in

which he lives, by

giving examples

from his daily life.

SB.5.3.3. It gives

examples of the

natural features of

the place and its

surroundings and

the effects of

human

characteristics on

the population and

settlement.

SB.5.3.4. Question

the causes of

disasters and

environmental 
Elbay, S. (2020). A Foundational Perspective for Spatial Thinking in Relation to Social Studies...

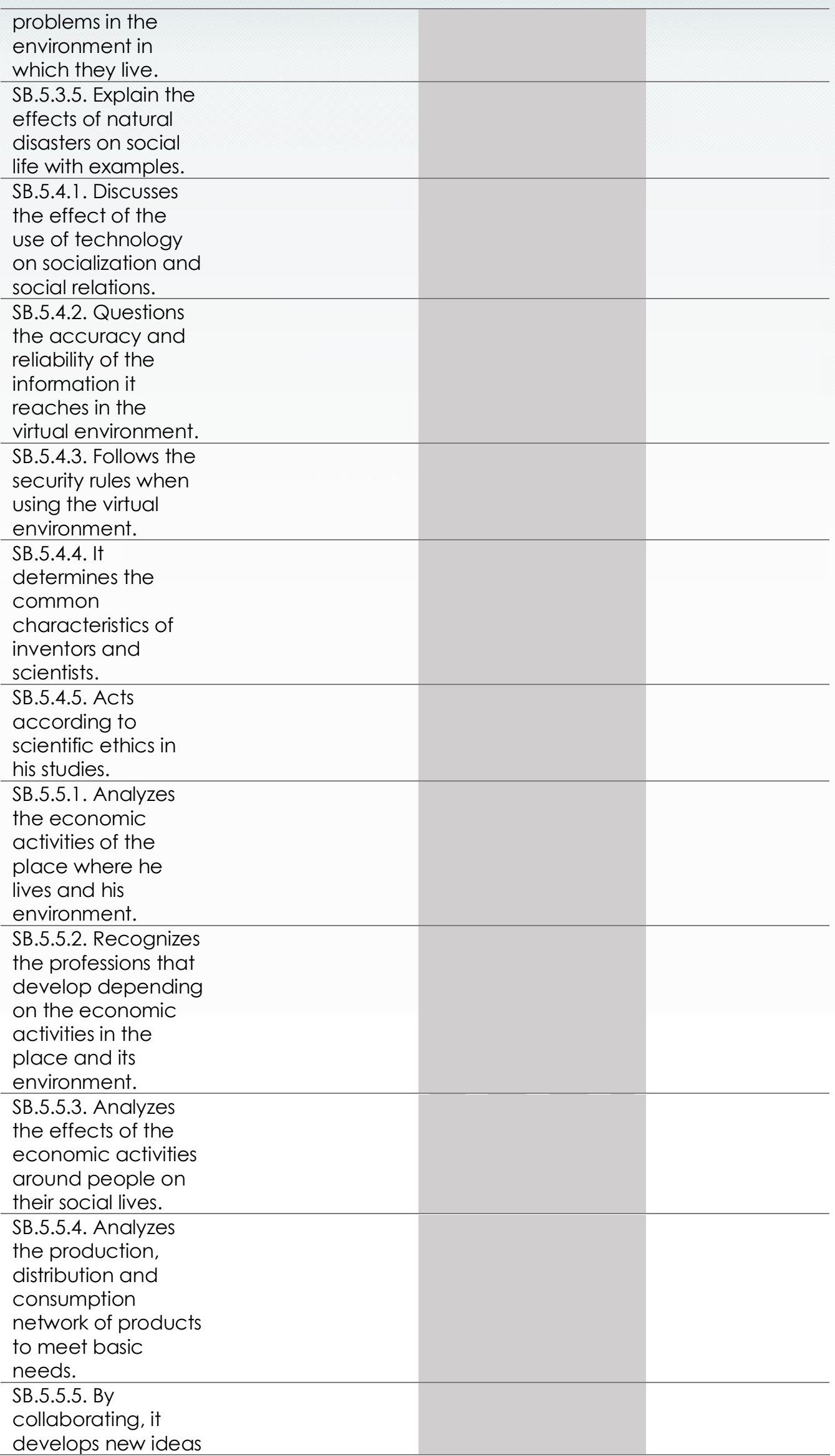




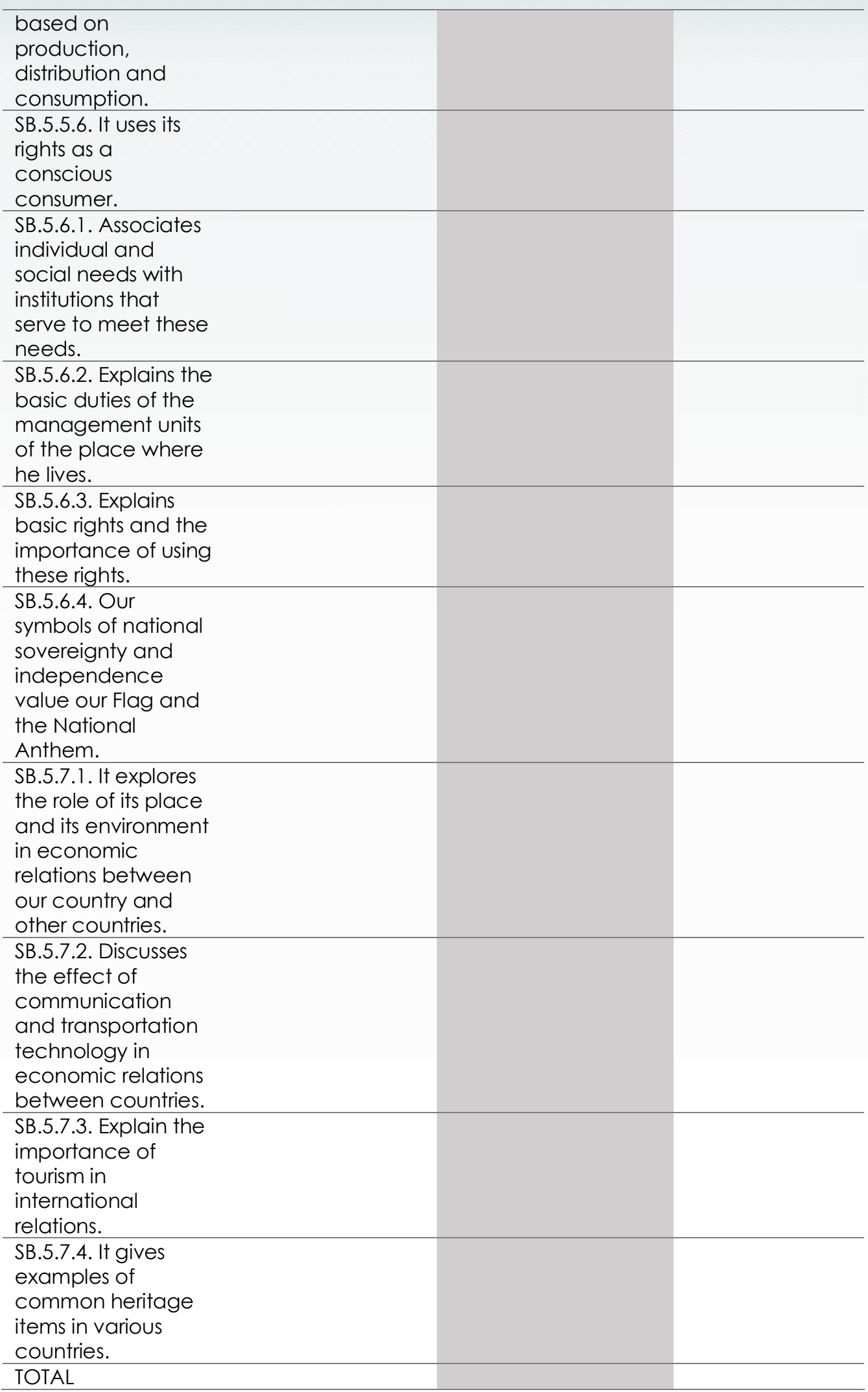


Elbay, S. (2020). A Foundational Perspective for Spatial Thinking in Relation to Social Studies...

\section{Biographical Statements}

Sezgin ELBAY is a teacher of Social Studies at Ministry of National Educational (MONE), Turkey. He received his B.A. (2009) degrees in social studies education from Afyon Kocatepe University and M.A. (2015) degrees in education management, control, planning and economics from Kahramanmaraş Sütçü İmam University. And he is also a Ph. D candidate in social studies education at Anadolu University, Institute of Educational Sciences. His current research interests include historical and spatial thinking skills, inquiry and fieldwork. He is also interested in designing lesson plans and new teaching ideas and sharing them with stakeholders. 